\title{
Potential effect of climate change on the distribution of palsa mires in subarctic Fennoscandia
}

\author{
Stefan Fronzek ${ }^{1, *}$, Miska Luoto ${ }^{2}$, Timothy R. Carter ${ }^{1}$ \\ ${ }^{1}$ Finnish Environment Institute, Box 140, 00251 Helsinki, Finland \\ ${ }^{2}$ Thule Institute, University of Oulu, Box 7300, 90014 Oulu, Finland
}

\begin{abstract}
Palsa mires are northern mire complexes with permanently frozen peat hummocks, located at the outer limit of the permafrost zone. Palsa mires have high conservation status, being characterized by a rich diversity of bird species and unique geomorphological processes. They are currently degrading throughout their distributional range, probably because of regional climatic warming. Distributions of palsas in Fennoscandia were modelled using 5 climate envelope techniques (generalized linear modelling, generalized additive modelling, classification tree analysis, artificial neural networks and multiple adaptive regression splines). The models were studied with respect to their sensitivity to altered climate. Climate change scenarios were applied to assess possible impacts on the palsa distribution during the 21st century. The models achieved a good to very good agreement with the observed palsa distribution and thus suggest a strong dependency on climate. Even small increases of temperature $\left(1{ }^{\circ} \mathrm{C}\right)$ and precipitation $(10 \%)$ resulted in considerable losses of areas suitable for palsa development. Of the 5 models tested, 3 predicted the total disappearance of regions suitable for palsa development with an increased mean annual temperature of $4{ }^{\circ} \mathrm{C}$. Under climate change scenarios based on 7 Atmosphere-Ocean General Circulation Models (AOGCMs) the models indicated that the degradation of palsas will proceed very quickly. All but one climate scenario resulted in the total disappearance of suitable regions for palsa development by the end of the 21st century. Potential impacts of degrading palsa mires on biodiversity and carbon balance are the loss of habitat for migrating bird species and the increase in $\mathrm{CH}_{4}$ emissions.
\end{abstract}

KEY WORDS: AOGCM $\cdot$ Climate envelope $\cdot$ Climate scenario $\cdot$ Palsa mire $\cdot$ Peatland $\cdot$ Permafrost Uncertainty

Resale or republication not permitted without written consent of the publisher

\section{INTRODUCTION}

Permafrost landforms and habitats are highly dependent on climatic conditions and have therefore been recognised as sensitive indicators of climate change (Nelson et al. 2001). Palsas, small mounds with a permanently frozen peat and mineral soil core, are characteristic geomorphological features of subarctic mire landscapes. Palsa mires are mire complexes that occur in the northern hemisphere, representing one of the most marginal permafrost features at the outer limit of the discontinuous permafrost zone (Luoto et al. 2004a). The diameter of palsas ranges from a few metres to several tens of metres and their height from $<1$ to $10 \mathrm{~m}$ (Seppälä 1986, 1988).
Palsa mires are biologically heterogeneous environments, and are particularly characterized by a rich diversity of bird species (CAFF 2001). From a nature conservation point of view, palsa mires are highly graded in Europe; they are 1 of the 65 priority natural habitat types listed in Annex one of the 'Habitats' Directive of the European Union (Anonymous 1999). Moreover, one of the strongest arguments for the conservation of palsa mires concerns their unique successional behaviour and cycle of development, in which vegetation, peat and ice all play a complex role (Seppälä 1986, 1988). These characteristics make palsas mires exceptional geomorphological formations in subarctic landscapes (Luoto et al. 2004b). 
The cycle of palsa formation is often initiated in locations of thin or discontinuous snow cover, where winter frost can penetrate more deeply into the soil (Seppälä 1986). Freezing of soil water initiates the growth of an ice core that leads to topographic heaving of the peat surface. During summer, the higher peat surface dries out, creating a layer of low thermal conductivity that insulates the frozen core against summer heating (Zuidhoff \& Kolstrup 2000). As the palsa continues to grow, the elevated surface is liable to be snow-free in successive winters. Eventually, degradation of the palsa begins when the extent of upheaval creates cracks in the surface where insulating snow starts to accumulate during the winter. The palsa then disintegrates into blocks that melt away during the frost-free season. The developmental cycle, from initiation to disintegration, can take between some hundreds and a few thousands of years (Seppälä 1988).

Their distinct morphology distinguishes palsas as good indicators of permafrost in mires (Luoto \& Seppälä 2003). In northern Europe, the optimal climatic conditions for palsa mires are in areas of low precipitation $(<450 \mathrm{~mm})$ with a mean annual temperature between -3 and $-5^{\circ} \mathrm{C}$ (Luoto et al. 2004a). They can be found in parts of Norway, Finland, Sweden and Iceland as well as the Kola Peninsula in Russia (Luoto et al. 2004b). Outside Europe, palsa mires are frequent in Canada, Alaska and Siberia (Seppälä 1988). The marginal locations of palsa mires make them especially sensitive to climatic fluctuations (Seppälä 1988). Local studies suggest that subarctic palsa mires in Europe (Sollid \& Sørbel 1998, Zuidhoff \& Kolstrup 2000, Luoto \& Seppälä 2003) and in North America (Payette et al. 2004, Camill 2005) are currently degrading, and the influence of climate change during the 20th century has been suggested as a likely cause.

The climate in Fennoscandia has experienced a warming in most areas during the 20th century. For instance, the mean annual temperature for Finland has increased by about $0.7^{\circ} \mathrm{C}$ (Jylhä et al. 2004). Increasing precipitation trends have been observed for regions in Norway (Hanssen-Bauer \& Forland 2000), Sweden (Alexandersson 2001) and northern Finland (Jylhä et al. 2004). These trends are projected to continue and strengthen during the 21st century according to climate scenarios derived from Atmosphere-Ocean General Circulation Models (AOGCMs). Projections for Finland based on 6 AOGCMs give a range of increases for mean annual temperature between 2.4 and $7.4^{\circ} \mathrm{C}$ and for annual precipitation of 6 to $34 \%$ between the baseline period 1961-1990 and the period 2070-2099, respectively (Jylhä et al. 2004).

These changes in temperature and precipitation could have profound impacts on the distribution of palsa mires in northern Fennoscandia. The objective of this study was to assess these potential impacts, specifically by: (1) investigating the sensitivity of the palsa distribution with respect to changes in climate. (2) Defining a critical climate change that constitutes a risk of the total disappearance of palsas in northern Fennoscandia. (3) Modelling the likely impact of future climate change on the distribution of palsas, based on projections from state-of-the-art climate models throughout the 21 st century.

To address these objectives, we related the spatial distribution of palsas with climatic variables. Statistical models of spatial distributions of species or habitats using climatic variables are often referred to as climate envelope models (Heikkinen et al. 2006). They are static, i.e. they do not incorporate a time dimension, but assume equilibrium of the modelled distribution with climatic conditions. Climate envelope models have been widely applied in recent years to assess the potential impacts of climate change on biodiversity patterns (Heikkinen et al. 2006), but only few examples exist for permafrost landforms and habitats (e.g. Hoelzle \& Haeberli 1995). The models developed in this study were analysed for their sensitivity to systematic perturbations in climate and by applying physically based climate change scenarios.

\section{MATERIALS AND METHODS}

\subsection{Study area}

The study area covers ca. $240000 \mathrm{~km}^{2}$ in northernmost Finland, Norway and Sweden with a southern border corresponding to the Arctic Circle (66 $\left.33^{\circ} \mathrm{N}\right)$ (Fig. 1). Altitudes range from sea level to the highest peak in Sweden, Kebnekaise, 2217 m a.s.l. The topography and climate vary widely across the study area. Mean annual temperature is highest at the Norwegian coast in the southwest corner of the study area $\left(4.7^{\circ} \mathrm{C}\right.$ averaged over 1961-1990) and lowest in the mountains of northern Sweden $\left(-6.0^{\circ} \mathrm{C}\right)$. On average during 1961-1990, annual precipitation totalled between $370 \mathrm{~mm}$ in northern Sweden and $2170 \mathrm{~mm}$ at the Norwegian coast near the Arctic Circle.

\subsection{Data}

The distribution of palsa mires in the study area has been mapped onto a regular grid with a cell size of $10 \times 10^{\prime}($ ca. $8 \times 15 \mathrm{~km})$ using aerial photography and previously published maps (Luoto et al. 2004a). The southern border was set to the Arctic Circle, even though that excluded some palsa occurrences further south in the Swedish mountains. Larger lake areas 


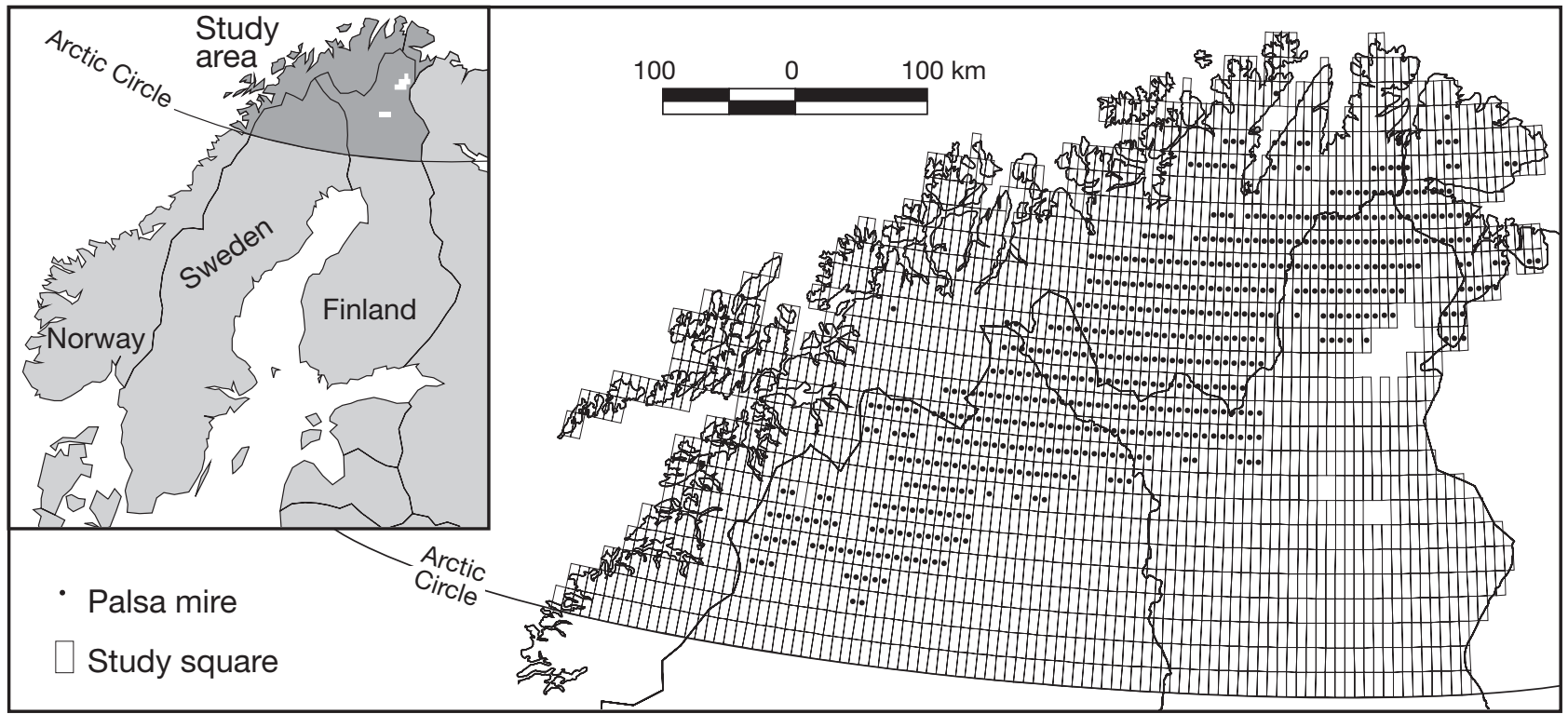

Fig. 1. Map of the study area showing palsa mire and study square location

such as Lake Inari were also excluded from the dataset. This resulted in 1913 grid cells, for which the presence or absence of palsas was recorded, with 545 grid cells $(28.5 \%)$ found to contain palsas.

Mean monthly temperature and monthly precipitation averaged for the 1961-1990 period and interpolated to the same grid as for the mapped palsa distribution were taken from the Climatic Research Unit (CRU) climatological database (New et al. 2002, Mitchell et al. 2003). The period 1961-1990 was adopted as the present-day reference in this study. The pattern of mean annual temperature and precipitation over the study area are depicted in Fig. 2.

Climate projections for the 21st century from 7 different AOGCMs were taken from the Data Distribution Centre of the Intergovernmental Panel on Climate Change (IPCC; http://ipcc-ddc.cru.uea.ac.uk) (Parry 2002). The data were averaged over three $30 \mathrm{yr}$ periods: 2010 to 2039, 2040 to 2069, and 2070 to 2099. The range of projections embrace uncertainties attributable both to climate model responses to forcing by greenhouse gas and aerosol emissions, and to 2 alternative forcings, A2 towards the upper and B2 towards the lower range of projected emissions by 2100 (Nakicenovic et al. 2000). The horizontal resolution of the AOGCM grids varies between $2.8 \times 2.8^{\circ}$ and $5.6 \times 5.6^{\circ}$ (Table 1). In order to match the resolution of the observational data, AOGCM data were linearly interpolated to the $10 \times 10^{\prime}$ observational grid. Climate scenarios for the 3 future $30 \mathrm{yr}$ mean periods were prepared by computing the change between climate modelled for the reference (1961-1990) and future periods and applying these changes as adjustments to the observed

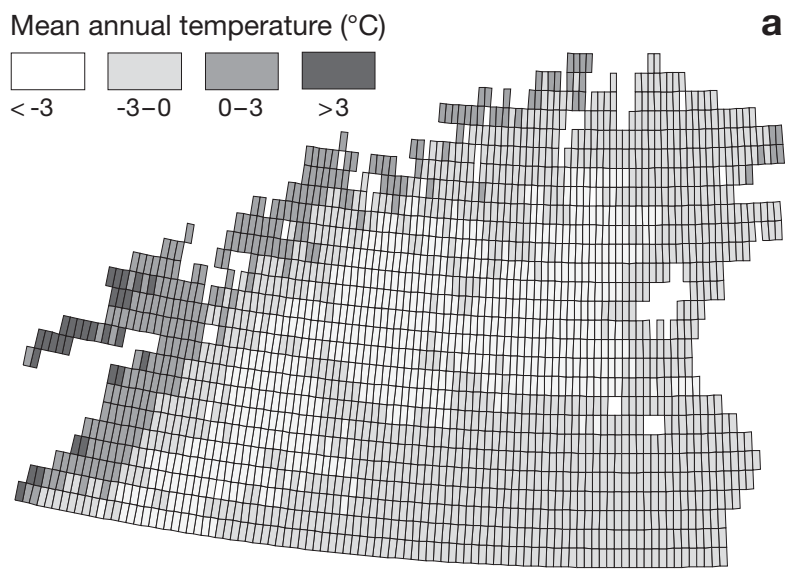

Mean annual precipitation $(\mathrm{mm}) \quad$ b

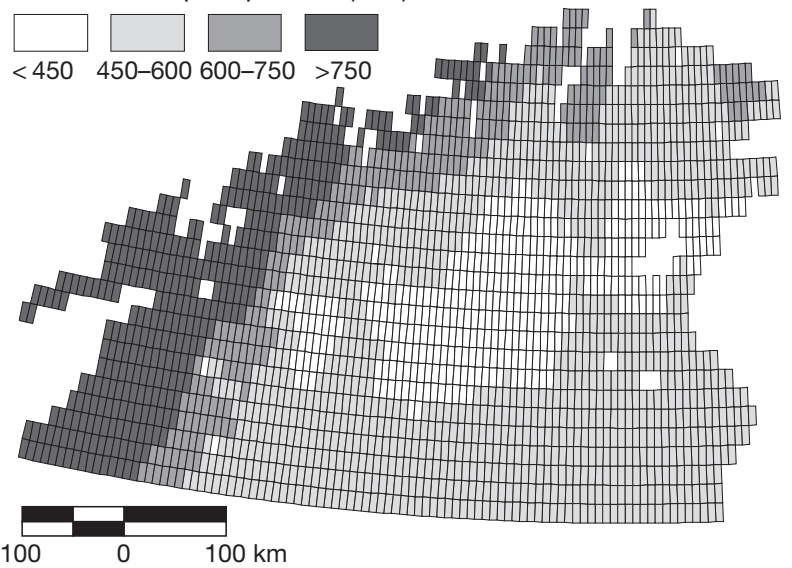

Fig. 2. Mean annual (a) air temperature and (b) precipitation in the study region (1961-1990) interpolated from meteorological stations to a $10 \times 10^{\prime}$ grid (Source: New et al. 2002) 
Table 1. Coupled AOGCMs utilized to construct climate scenarios for Fennoscandia with the size of their grid cells, the number of cells in the study area (No. of cells) and their estimated global mean temperature $\left(\Delta \mathrm{T}_{\text {glob }}\right)$ change between 1961-1990 and 2070-2099 (modified from Ruosteenoja et al. 2003)

\begin{tabular}{|c|c|c|c|c|c|}
\hline Model & Country & $\begin{array}{c}\text { Grid size } \\
\left({ }^{\circ}\right)\end{array}$ & $\begin{array}{l}\text { No. of } \\
\text { cells }\end{array}$ & $\begin{array}{c}\Delta \mathrm{T}_{\text {glob }} \\
\left({ }^{\circ} \mathrm{C}\right)\end{array}$ & Source \\
\hline CCSR/NIES & Japan & $5.6 \times 5.6$ & 8 & 4.4 & Emori et al. (1999) \\
\hline CGCM2 & Canada & $3.8 \times 3.8$ & 18 & 3.5 & Flato \& Boer (2001) \\
\hline CSIRO Mk2 & Australia & $3.2 \times 5.6$ & 12 & 3.4 & Gordon \& O'Farrell (1997) \\
\hline ECHAM4/OPYC3 & Germany & $2.8 \times 2.8$ & 21 & 3.3 & Roeckner et al. (1999) \\
\hline GFDL R30 & USA & $2.2 \times 3.8$ & 18 & 3.1 & Delworth et al. (2002) \\
\hline HadCM3 & UK & $2.5 \times 3.8$ & 12 & 3.2 & Gordon et al. (2000) \\
\hline NCAR PCM & USA & $2.8 \times 2.8$ & 21 & 2.4 & Washington et al. (2000) \\
\hline
\end{tabular}

The method to calculate daily temperature sums as shown in Eq. (1) requires daily temperature information, whereas the data for the observed as well as the modelled climate used in this study were only available at a monthly resolution. We used a method suggested by Kauppi \& Posch (1985) to estimate the ETS using monthly mean temperature. In their method, the ETS function in Eq. 1 is integrated over an assumed Gaussian daily temperature distribution. This method requires the SD of daily mean temperatures about the monthly mean. For this purpose, an

1961-1990 reference data. Adjustments to temperature were given as differences $\left({ }^{\circ} \mathrm{C}\right)$ and to precipitation as ratios $(\%)$.

\subsection{Derivation of climatologically explanatory variables}

Four explanatory variables were derived from the observational climate data for each cell of the raster grid (cf. Table 2) consisting of annual precipitation (APREC), a continentality index (CONT), thawing degree-days (TDD) and freezing degree-days (FDD). CONT described the range of the seasonal cycle of temperature and was calculated as the difference between the minimum and the maximum of all monthly mean temperature values. TDD and FDD were based on the effective temperature sum (ETS), which can be approximated by the accumulated sum of mean daily temperatures above (or below) a certain base temperature (Carter et al. 1991):

ETS $=\sum_{i=1}^{n} \delta_{i}\left|T_{i}-T_{b}\right|, \quad$ where $\delta=\left\{\begin{array}{l}1 \text { for } T_{i}>(<) T_{b} \\ 0 \text { for } T_{i} \leq(\geq) T_{b}\end{array}\right.$

$T_{i}$ denotes the mean temperature at day $i, T_{b}$ the base temperature and $n$ the length of the summation period. For thawing and freezing degree-days, the base temperature $T_{b}$ is set to $0^{\circ} \mathrm{C}$ and the summation is performed over all days of the year, for the former above the freezing temperature and for the latter below. interpolated grid-dataset for Europe of daily SDs around the monthly mean temperature developed in a previous project was employed (Fronzek \& Carter 2006). This was based on observed daily station data for the 1961-1990 period obtained from 2 sources: the European Climate Assessment (Klein Tank et al. 2002) and the Finnish Meteorological Institute (Heikki Tuomenvirta pers. comm.). Point values of SDs for stations were computed for each month and interpolated to the $10 \times 10^{\prime}$ resolution grid over Europe using the kriging method with a spherical model for the variogram.

\subsection{Distribution modelling and model application}

The presence/absence response variable and the explanatory variables were combined in a GIS for the study area. The data were divided into a calibration and an evaluation data set, using a random selection method on the stratified palsa presence/absence data; $70 \%$ of the grid cells with present palsa records and $70 \%$ of the absent records were randomly selected as a calibration set. The remaining $30 \%$ formed the evaluation set. Guisan \& Zimmermann (2000) regard the socalled 'split-sample approach' applied here as appropriate for sufficiently large data sets, though they note that the calibration and evaluation sets are not totally independent. Three different random sets were applied in developing models to test for dependence of model performance on the random selection of data points.

Table 2. Definition of climatological explanatory variables

\begin{tabular}{|lll}
\hline & Variable & Definition \\
\hline APREC & Annual precipitation & January-December sum of monthly precipitation \\
CONT & Continentality & Annual thermal interval, maximum - minimum of all monthly mean temperatures \\
TDD & Thawing degree days & Accumulated daily temperature sum above $0^{\circ} \mathrm{C}$ \\
FDD & Freezing degree days & Accumulated daily temperature sum below $0^{\circ} \mathrm{C}$ \\
\hline
\end{tabular}


The climatic variables were related to the palsa distribution data using 5 alternative statistical methods: Generalized Linear Modelling (GLM), Generalized Additive Modelling (GAM), Classification Tree Analysis (CTA), Artificial Neural Networks (ANN), and Multiple Adaptive Regression Splines (MARS). This allowed a comparison of the methods' predictive ability and a quantification of uncertainties deriving from the choice of the modelling approach. These 5 methods represent modern statistical or rule-based techniques with conceptionally differing model structures (Thuiller et al. 2003):

- GLM with a logistic link function was used to fit the palsa occurrences to the climatic explanatory variables. The logistic link function utilizes a linear combination of the explanatory variables, the linear predictor (Luoto \& Hjort 2004). We used GLM with linear, second and third order terms with a stepwise backwards-dropping procedure to select the most significant variables using a strict criterion of $\mathrm{p}<$ 0.001 .

- GAM is an expansion of GLM that relaxes the linear predictor by introducing non-linear smooth functions. GAM thereby offers a more flexible model structure (Thuiller et al. 2003). We selected significant explanatory variables $(p<0.001)$ using smoothing splines of up to 4 degrees of freedom applying a stepwise backward-dropping procedure.

- ANN are non-linear models introducing different levels for combining the explanatory variables, the so-called hidden layers. Increasing the number of hidden layers introduces more flexibility but also risks an over-fitting of the model (Moisen \& Frescino 2002). We trained an ANN implemented in the nnet library of Splus with 7 single hidden layers including skip-layer units using the linear and quadratic terms of the explanatory variables (Venables \& Ripley 2002). As ANN depends on random initial conditions, this was repeated 10 times to test the stability of the model structure.

- CTA subdivides the space spanned by the explanatory variables into regions in which the response variable is approximately equal (Moisen \& Frescino 2002). A tree is built by repeatedly splitting the data based on thresholds for individual explanatory variables to define the borders of the regions (Thuiller et al. 2003). We used the tree library of Splus to build a regression tree of the palsa distribution (Venables \& Ripley 2002).

- MARS combine classical linear regression with classification techniques and generalize the piecewise constant functions of CTA to continuous functions by fitting spline curves (Moisen \& Frescino 2002). This technique represents a flexible nonparametric regression method. A MARS model was calibrated using the mda library of Splus with an interaction degree of 1 and a cost per df charge of 3 (Venables \& Ripley 2002).

The statistical techniques and their applications in geomorphological mapping are introduced and discussed in more detail by Luoto \& Hjort (2004).

The resulting model predictions $\pi$ are values between 0 and 1 , which can be interpreted as the probability of a palsa occurrence for the specific conditions of the explanatory variables. The 5 models were evaluated using the area under the receiver operating characteristics curve (AUC) and the Kappa coefficient of agreement. This was carried out using the evaluation data set. Analysis of AUC is a threshold-independent method to evaluate model predictions (Guisan \& Zimmermann 2000). The AUC value expresses the ability of a model to discriminate between the presence and absence of palsas (Pearce \& Ferrier 2000). An approximate guide for classifying the accuracy of AUC is provided by Swets (1988): 0.9-1.0 = excellent; $0.8-0.9=$ good $_{i}$ $0.7-0.8=$ fair $; 0.6-0.7=$ poor $; 0.5-0.6=$ fail. The Kappa coefficient is a measure of proportional agreement between observations and predictions adjusted for agreement that might occur by chance. It was used to determine the best threshold that translates probabilistic predictions $(\pi)$ to predictions of presence or absence by maximising the Kappa statistics. Monserud \& Leemans (1992) suggested the following scheme to describe the level of agreement: $0.99-1.00=$ perfect; $0.85-0.99=$ excellent; $0.70-0.85=$ very good; $0.55-0.70=$ good; $0.40-0.55=$ fair $; 0.20-0.40=$ poor $; 0.05-0.20=$ very poor $;$ $<0.05=$ no agreement

Following model evaluation, each palsa distribution model was studied with respect to its sensitivity to changes in temperature and precipitation. Constant changes were applied to all monthly grid observations of climate data. Changes in temperature of between $-2^{\circ} \mathrm{C}$ and $6^{\circ} \mathrm{C}$ at $1^{\circ} \mathrm{C}$ intervals, and of precipitation between $-20 \%$ and $+30 \%$ at $10 \%$ intervals were investigated. Combinations of temperature and precipitation change were not examined. The palsa models were also run for grid observations adjusted according to 14 climate change scenarios. These were derived from 7 AOGCMs assuming 2 emissions scenarios for the periods 2010-2039, 2040-2069, and 2070-2099. The explanatory variables used in the palsa model were calculated for each climate change scenario and used to predict the palsa distribution.

\section{RESULTS}

Descriptive statistics of the model performance of 5 different statistical techniques are presented in Table 3. AUC values for the evaluation data set varied 
Table 3. Evaluation table of the 4 palsa distribution models. Kappa and AUC statistics $( \pm$ SE) for the calibration $(n=1338)$ and evaluation $(n=573)$ data sets

\begin{tabular}{|lccccc|}
\hline \multirow{2}{*}{ Model } & \multirow{2}{*}{ Threshold } & \multicolumn{2}{c}{ Calibration } & \multicolumn{2}{c|}{ Evaluation } \\
& & Kappa & AUC & Kappa & AUC \\
& & & & \\
GLM & 0.47 & $0.773 \pm 0.02$ & $0.957 \pm 0.01$ & $0.714 \pm 0.03$ & $0.943 \pm 0.01$ \\
CTA & 0.45 & $0.856 \pm 0.02$ & $0.986 \pm 0.00$ & $0.692 \pm 0.03$ & $0.919 \pm 0.01$ \\
GAM & 0.51 & $0.778 \pm 0.02$ & $0.961 \pm 0.00$ & $0.720 \pm 0.03$ & $0.948 \pm 0.01$ \\
MARS & 0.47 & $0.734 \pm 0.02$ & $0.952 \pm 0.01$ & $0.691 \pm 0.03$ & $0.941 \pm 0.01$ \\
ANN & 0.51 & $0.794 \pm 0.02$ & $0.950 \pm 0.01$ & $0.721 \pm 0.03$ & $0.920 \pm 0.01$ \\
\hline
\end{tabular}

The sensitivity analysis showed considerable impacts of changes in temperature and precipitation on the modelled distribution of palsas (Figs. 4 \& 5). Model predictions with GAM which was evaluated highest in terms of AUC and second highest in terms of the Kappa values (Section 3.1) are presented in Fig. 4. Predictions showed that decreased precipitation expands the areas with predicted palsas in all

between 0.92 and 0.95 for the 5 models, indicating the models' capability to discriminate correctly between occupied and unoccupied sites. The lowest AUC value was obtained with CTA, whereas the highest value was achieved by GAM. The thresholds for translating probabilistic predictions to presence/absence values varied between 0.45 and 0.51 for the 5 models. Kappa coefficients in the evaluation data set varied between 0.69 and 0.72 , indicating that the percentage accuracy of the model predictions is better than the results of a random assignment. The lowest Kappa value was obtained with MARS, the highest with ANN.

Model results are shown in Fig. 3, in which correct and false predictions of the 5 approaches are mapped. The general pattern of the spatial distribution of palsas is well captured in all models with incorrect predictions mainly occurring in individual grid cells at the edges of the observed palsa distribution. An exception is the southwest corner of the studied palsa distribution where CTA is the only model that correctly predicts the presence of palsas. These grid cells are located in the region with the highest altitude of the study area in the Swedish mountains. directions, whereas decreased temperatures of $-2^{\circ} \mathrm{C}$ resulted in expansion only towards the southeast from the current distribution (Fig. 4e-h). An imposed warming, on the other hand, reduced the palsa distribution from both the northeast and south towards the centre of the current distribution (Fig. $4 \mathrm{a}-\mathrm{d}$ ). Increased precipitation led to a fairly uniform shrinkage of the palsa distribution in all directions.

A critical climate change was reached with increased temperatures of $4^{\circ} \mathrm{C}$, for which 3 models (GLM, GAM, ANN) predicted the total disappearance of palsas in the study area, and the remaining 2 models predicted a remaining suitable area of $0.4 \%$ (CTA) and $15.8 \%$ (MARS) compared to the present distribution. However, the area suitable for palsas is already considerably reduced with much smaller temperature changes: the number of suitable grid cells was reduced by more than half with a warming of $1^{\circ} \mathrm{C}$ and to less than one fifth with a warming of $2^{\circ} \mathrm{C}$ in 3 of the 5 models (Fig. 5a). Moreover, increases in precipitation also led to a considerable reduction in modelled suitability (down to 49-69\% of the original area for an increase of $10 \%$; Fig. 5b). No model predicted a total loss in
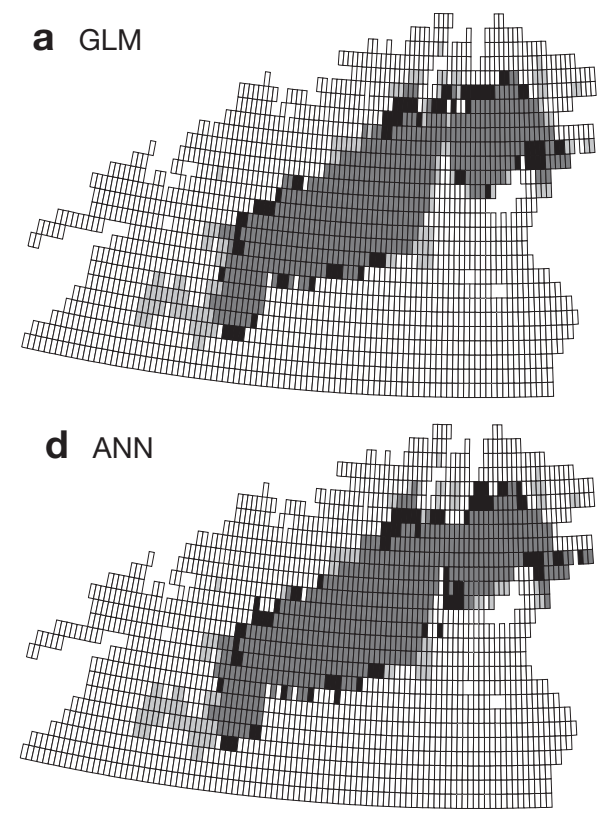
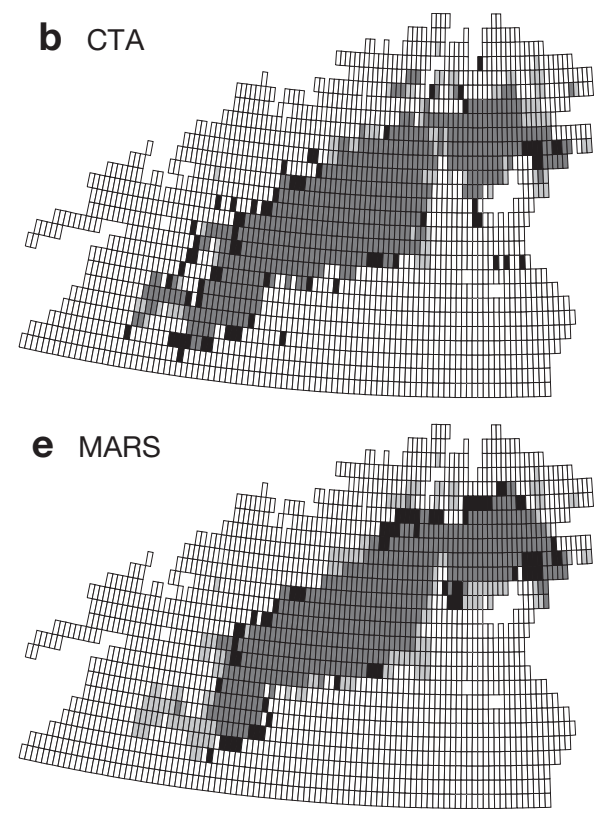
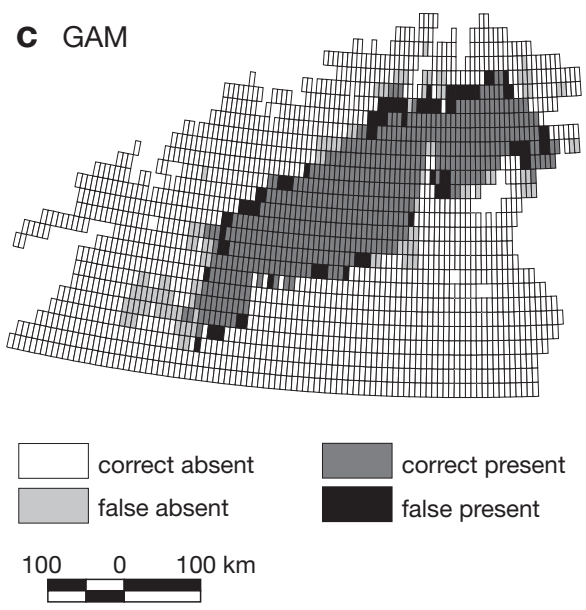

Fig. 3. Correct and false predictions of the current palsa mire distribution using (a) GLM, (b) CTA, (c) GAM, (d) ANN and (e) MARS 
Fig. 4. Temperature and precipitation sensitivity of the palsa distribution model using GAM. The monthly temperature values have been modified by (a) $-1^{\circ} \mathrm{C}$, (c) $+1^{\circ} \mathrm{C}$ and (d) $+2^{\circ} \mathrm{C}$. Annual precipitation totals have been modified by (e) $-10 \%$, (g) $+10 \%$ and $(\mathrm{h})+20 \%$. Maps of model predictions for the baseline climate are shown in (b) and (f). The predicted occurrence of palsa mires is shown with solid black grid cells, the prediction of their absence is shown with white grid cells
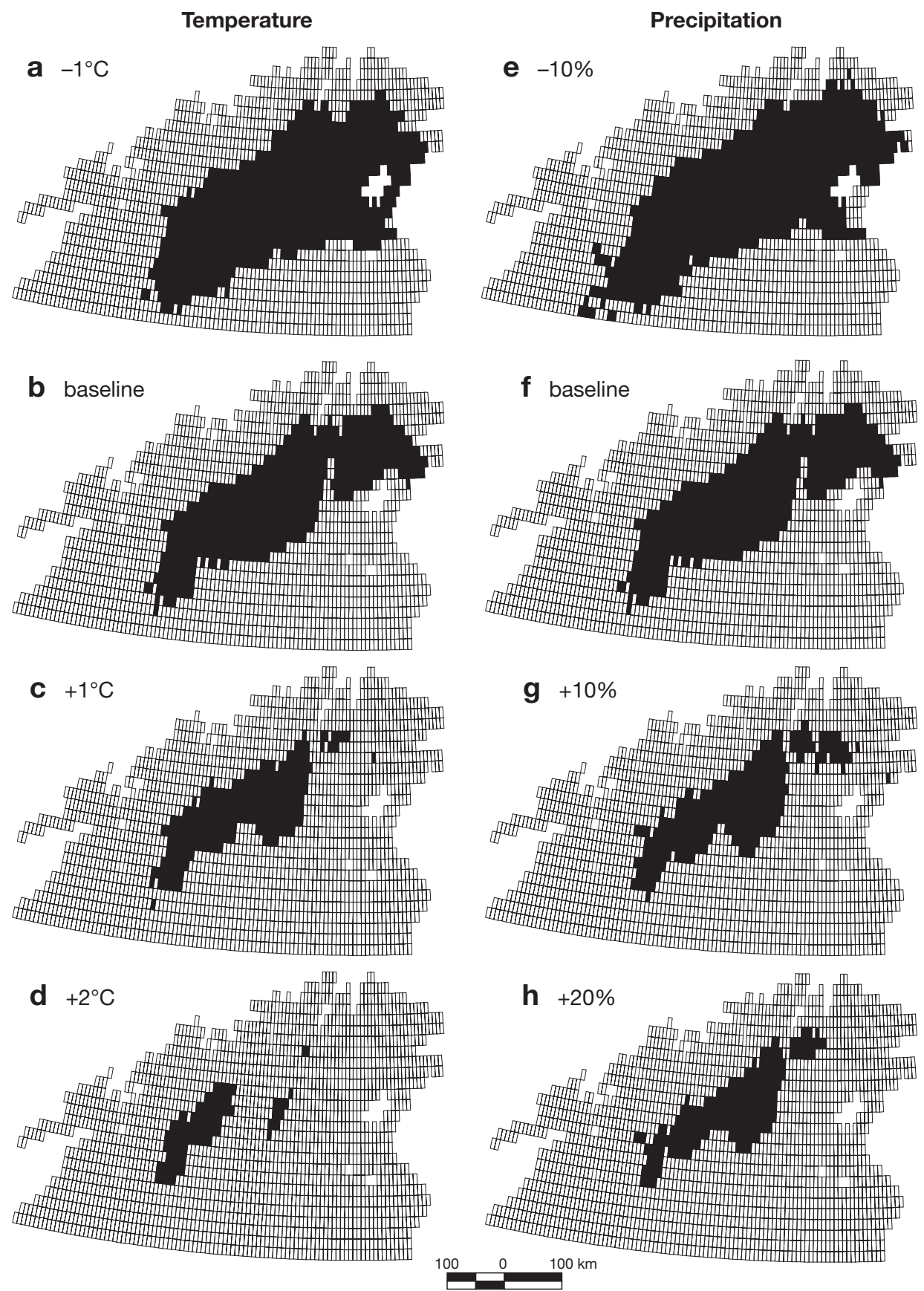

suitable areas due to precipitation changes across the range examined $(-10 \%$ to $+30 \%)$.

The application of GCM-based scenarios with the GAM model (which ranked highest in the model evaluation) produced reductions in suitability to less than half of the current palsa area by the period 2010-2039 for all 7 GCMs under both the SRES A2 and B2 emission scenarios (Fig. 6). Three scenarios predicted the total disappearance of palsa mires by the period 2040-2069 (CGCM2, A2; CCSR/NIES, A2 and B2), and for the period 2070-2099, only 1 scenario (GFDL-R30,
B2) showed a few remaining areas with palsas, covering only about $3.5 \%$ of the original distribution. Maps of model predictions using GAM are shown for 2 GCM scenarios in Fig. 7. The ECHAM4/OPYC3 scenario with SRES A2 forcing resulted in a rapid reduction of suitable area to 2 small patches by the first scenario period, 2010-2039. The patches were further reduced in the following time period and totally disappeared by the end of the 21st century. Palsa predictions with the GFDL-R30 scenario with SRES B2 forcing were at the lower end of the uncertainty range spanned by the 

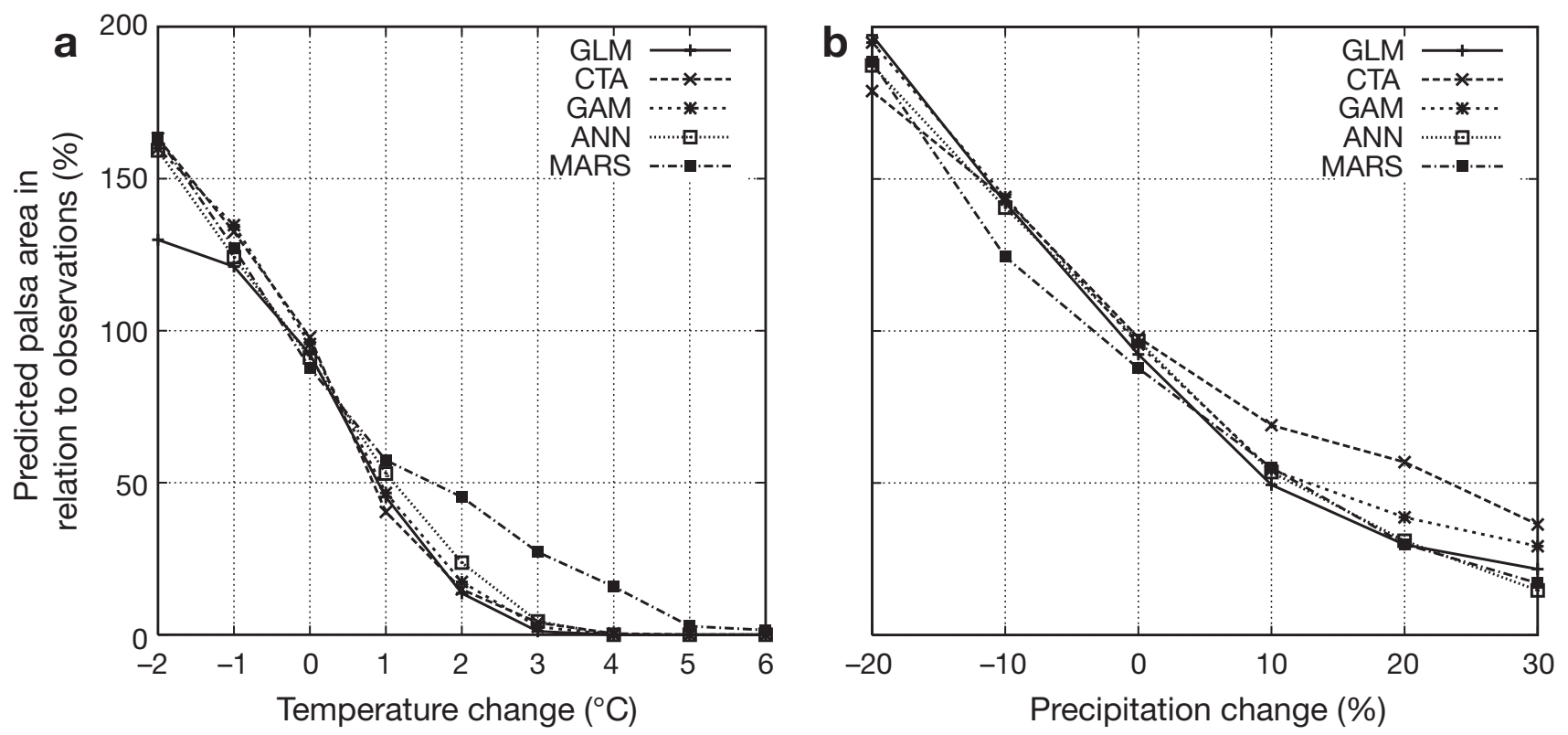

Fig. 5. Predicted changes of palsa occurrence relative to observations for changes in (a) temperature and (b) precipitation with 5 different models

GCM scenarios. A reduction by $70 \%$ in the areas suitable for palsas was predicted for the period 2010-2039; however, the period 2040-2069 showed relatively little further reduction in suitable area.

\section{DISCUSSION}

\subsection{Modelling the current palsa distribution}

The results of the 5 modelling approaches applied here were broadly concordant, demonstrating that all were capable of describing the current distribution of palsa mires in northern Fennoscandia. The agreement of the modelled with the observed palsa distribution is 'good' to 'very good' according to the Kappa statistics (Monserud \& Leemans 1992) and excellent according to the AUC values (Swets 1988) (Table 3). This fit of the models was achieved using 4 climatological explanatory variables alone.

The unexplained variation of the palsa distribution can be attributed, at least in part, to missing climatological information such as snow cover and to non-climatological factors, the most important probably being soil type. Vegetation may also play an important role in the formation of palsas, e.g. by influencing the distribution and physical characteristics of snow and consequently the thermal insulation of palsas during the winter (Seppälä 1988). The existence of shrubs deter- mines local wind patterns, which have been reported to influence palsa formation by causing abrasion of the peat layer (Seppälä 2003). Soil and vegetation are themselves influenced by climate and therefore difficult to include in a static model that is developed for climate scenario applications (Guisan \& Theurillat 2000).

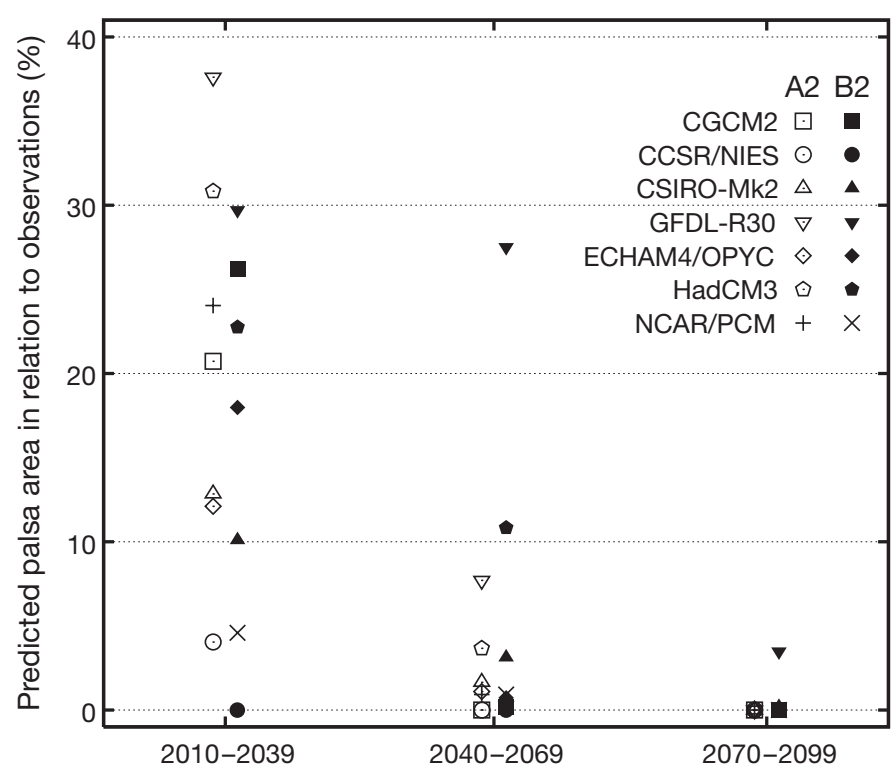

Fig. 6. Predicted changes of palsa occurrence relative to observations according to climate scenarios for three 30 year time slices in the 21st century. Seven GCMs were forced by 2 emission scenarios, SRES A2 and B2 (see Table 1) 

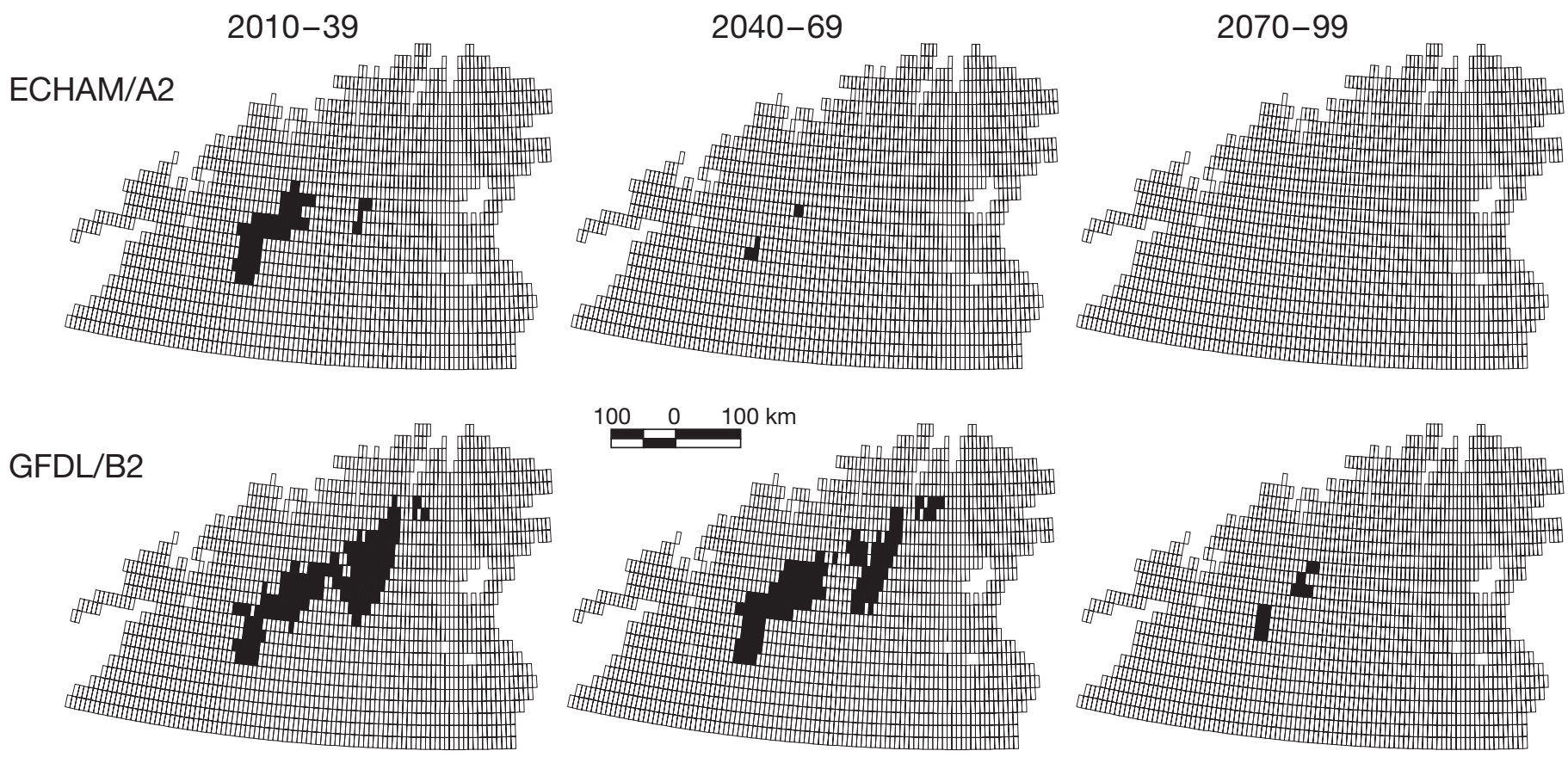

Fig. 7. Palsa mire distribution according to 2 climate scenarios for 2010-2039, 2040-2069 and 2070-2099 predicted with the GAM distribution model. The scenario in the top row of maps uses climate changes simulated with the ECHAM/OPYC3 AOGCM with a forcing according to the A2 emission scenario. The bottom row shows results with the GFDL AOGCM under the B2 scenario. The predicted occurrence of a palsa mire is shown with solid black grid cells, the prediction of their absence is shown with white grid cells

Both the AUC and Kappa values are higher when calculated for the calibration data than with the evaluation data (Table 3). While this is a logical consequence of the model calibration, these differences are relatively modest for GLM, GAM, ANN and MARS. The differences for CTA are somewhat larger: the Kappa value decreases from 0.856 to 0.692 and the AUC value from 0.986 to 0.919 between calibration and evaluation data sets. Luoto \& Hjort (2004) found similar behaviour using CTA when evaluating the predictive ability for geomorphological mapping. The predictive power of CTA models may often be rather low due to over-fitting (Moisen \& Frescino 2002, Venables \& Ripley 2002, Thuiller et al. 2003).

The accuracy of the palsa distribution models was validated here by a split-sample approach. However, it may not avoid 2 of the most important pitfalls of correlative models, namely spatial and temporal autocorrelation in the calibration and evaluation sets. Spatial autocorrelation in the dependent and explanatory variables creates a severe problem, because correlative modelling techniques assume that modelled events are independent, which is not true in the case of spatially autocorrelated data (Araújo et al. 2005). This problem is not overridden by a split-sample approach, because evaluation data is spatially autocorrelated with data to calibrate models. The autocorrelation of the data makes it conceptually difficult to eliminate the possibility that models' goodness-of-fit to the data represent an over-optimistic estimate of their predictive ability outside the initial spatial and temporal conditions defining the calibration set (Araújo et al. 2005).

\subsection{Modelling the effect of climate change on palsa distribution}

Latitudinal or altitudinal expansion in the range of palsa mires under decreasing temperature and precipitation might not occur as predicted, because the distribution of palsa mires is also limited by other physical factors. One is peat thickness, which is essential to insulate the frozen core of a palsa (Seppälä 1988). At present, tundra mires to the north of, or at higher elevations, than the present palsa distribution do not possess enough peat for the formation of palsas (Walter \& Breckle 1989). This constraint on palsa migration makes them extremely vulnerable to a changing climate.

The climate envelope models presented here assume the palsa distribution to be in equilibrium with current climatic conditions and thus neglect dynamic interactions. Consequently, the possibility of a time lag in the response of the palsa distribution following a change in climate is not directly taken into account. 
The time span of natural degradation of a palsa under constant climatic conditions is often difficult to determine. Degradation may take place within a few years, for instance as reported by Luoto \& Seppälä (2003) for a $5 \mathrm{~m}$ high palsa that melted entirely within $10 \mathrm{yr}$. But degradation can also last longer for large palsa plateaux (Sollid \& Sørbel 1998). It can also be argued that the rate of thawing is accelerated under warmer and wetter climatic conditions and a possible time lag between changed climate conditions and permafrost thawing is likely to be shorter than the time span of natural palsa degradation.

An alternative approach might have been to develop a model describing the heat and mass transfer in subarctic soils leading to the cyclic development of palsas. For example, An \& Allard (1995) developed a 1-dimensional heat and mass transfer model and simulated the formation of palsas for site conditions in Northern Quebec, Canada. However, incorporating the necessary detail of local soil and hydrological conditions to such a mechanistic model at the regional scale of the present study presents a challenging task. Statistical techniques have more modest data requirements and their application is justified to estimate climate change impacts on the distribution of palsa mires.

Statistical relationships like the ones developed in this study do not necessarily hold true if they are applied with values of the explanatory variables that fall outside the range of the calibration sample. This is often the case with applications of climate scenarios in which climate events lie outside the range of presentday variability (Parry \& Carter 1998, p. 41). A general strategy to overcome this deficiency is to use a calibration sample that covers a sufficiently large range of values in the explanatory variables. However, the warmest and wettest grid cells in the study area will necessarily drop out of this range when scenarios of climate change are applied to them. Modelling results in these areas should therefore be investigated very carefully.

Unlike some living organisms, palsas are incapable of 'adapting' to climate change. The laws of thermodynamics and the constraints of the natural environment determine the physical parameters for the formation of palsas. They are controlled, for example, by moisture and soil conditions that allow ice segregation, insulation above the ground and near-surface temperature (An \& Allard 1995). Therefore, the statistical relationships between the palsa distributions found for the present-day climate are likely to also hold true for warmer and wetter climatic situations. This is especially true for those areas of model application that experience similar climatic and physical conditions as that of the calibration sample.
Luoto \& Seppälä (2003) describe recent thawing of palsas in a $3370 \mathrm{~km}^{2}$ study area in Finnish Lapland, which is part of the area modelled in the present study. They show that palsas are collapsing and melting more often than new ones are forming. These findings coincide with the model predictions of reduced suitability in the corresponding grid cells for all scenarios of climate warming. Our models predict the loss of palsas for the same area due to increasing temperature (cf. Fig. 4) and for a part of the area due to increased precipitation. This suggests that the area exhibits a climate very close to the limit for palsa generation and that small changes in temperature and rainfall will very rapidly affect existing palsas. Other studies show empirical evidence of a shrinking palsa distribution in Fennoscandia outside the model area (Sollid \& Sørbel 1998, Zuidhoff \& Kolstrup 2000).

\subsection{Implications of declining palsa mires}

The anticipated decline in palsa mire areas can be expected to have significant implications for the ecology (Luoto et al. 2004b) and carbon balance (Christensen et al. 2004) of the region. Melting of the underlying permafrost changes the physical soil foundations that determine surface micro-topography and hydrology. This in turn will influence the plant composition and habitat suitability for birds. The loss of permafrost and consequent wetter conditions in the mires are likely to increase greenhouse gas emissions and could therefore provide a feedback mechanism to the climate system.

In Fennoscandia, palsa mires are well known for their rich bird life (CAFF 2001). The regional density and species richness of birds breeding in peatlands increases northwards in Europe, and in the case of North European waders reaches a maximum in the palsa mire zone (Järvinen \& Väisänen 1976). Of 11 biotopes in Finnish Lapland, the density and species richness of both passerines and waders are highest in palsa mires. The density of all bird species in palsa mires (262 pairs $\mathrm{km}^{-2}$ ) is more than double that of the second highest value (103 pairs $\mathrm{km}^{-2}$ ) from alpine peatlands (Järvinen \& Väisänen 1976).

The abundance of birds in subarctic palsa mires is thought to be based on 2 ecological factors: habitat heterogeneity and the existence of shallow waters that provide a plentiful source of food (insects, especially dipterans) for birds during the hatching period (Järvinen \& Väisänen 1976). Thus the potential consequences of the degradation of palsas for bird populations depends on what happens to the overall heterogeneity of palsa mires and to water hollows (Luoto et al. 2004 b). It is obvious that the heterogeneity of Fenno- 
scandian palsa mires will, to some extent, decrease as the palsas themselves melt and collapse (Sollid \& Sørbel 1998; Fig. 7). If degradation takes place in several palsa mires, the regional bird populations may well be affected. This potential decline may be reinforced by higher year-to-year variation of populations in the palsa region compared to more southerly areas, and for this reason populations may be more vulnerable and disappear more easily (Luoto et al. 2004b).

Degrading palsas also have an impact on the climate through changes in the peatland carbon dioxide $\left(\mathrm{CO}_{2}\right)$ and methane $\left(\mathrm{CH}_{4}\right)$ dynamics. Palsas have lower $\mathrm{CH}_{4}$ emissions than wet peatland surfaces, but small changes in the water table can cause increased emissions. Christensen et al. (2004) estimated an increase of $\mathrm{CH}_{4}$ emissions of 22 to $66 \%$ in a single subarctic mire in Sweden during the period 1970 to 2000 and connected this trend to disappearing permafrost and changes in the vegetation. Though local conditions of individual palsa mires can vary considerably, an overall increasing trend of $\mathrm{CH}_{4}$ emissions with degrading palsas seems probable.

\section{CONCLUSIONS}

Our results indicate that the distribution of palsas in Fennoscandia is very sensitive to climate change. Increasing temperature and precipitation will reduce the area that is suitable for palsa development. Predictions with 5 alternative statistical models indicate that an increase of $4{ }^{\circ} \mathrm{C}$ in mean annual temperature will result in the loss of all palsa mires in northern Fennoscandia. Furthermore, estimates using climate scenarios for the 21st century indicate that the areas suitable for palsa mires will already have declined considerably by the period 2010-2039. By the end of the 21st century, conditions promoting the development of palsa mires may have disappeared entirely. This is likely to have ecological consequences for the palsa regions, especially for the diversity of bird species, as well as constituting an additional (if temporary) source of greenhouse gas emissions to the atmosphere.

Incorporating more detailed information into the statistical distribution models can further reduce uncertainty in model estimates for the distribution of Fennoscandian palsa mires. This could be finer scale information on the location of palsa mires or other relevant environment and climatic data, which were not available for this study. Most notably, accurate information about the snow cover and soil conditions can be expected to improve model results. The distribution models presented here could also be tested in palsa mire areas outside Fennoscandia, if data for the evaluation of the estimates were available. Finally, the development of mechanistic models of palsa formation and decay, including descriptions of heat and mass transfer processes, could potentially reduce uncertainties in predictions for scenarios of climate that are outside the range of present-day conditions.

Acknowledgements. This work was carried out as part of the European Union-funded project ALARM (Assessing large scale environmental risks for biodiversity with tested methods GOCE-CT-2003-506675). Supplementary funding was obtained from the Finnish Environment Institute (FINESSI project), the Academy of Finland (decision 106979), and the European Union-funded project ENSEMBLES (GOCE-CT-2003-505539). Two anonymous referees and R. K. Heikkinen provided constructive comments on an earlier draft of this manuscript.

\section{LITERATURE CITED}

Alexandersson H (2001) Homogenisation of climate data, difficult but necessary. In: India MB, López D (eds) Detecting and modelling regional climate change. Springer-Verlag, Berlin, p 3-12

An W, Allard M (1995) A mathematical approach to modelling palsa formation: insights on processes and growth conditions. Cold Regions Sci Tech 23:231-244

Anonymous (1999) Interpretation manual of European Union habitats. Eur 15 / 2 European Commission, DG environment, nature protection, coastal zones and tourism. Available at: http://europa.eu.int/comm/environment/nature/hab-en.htm

Araújo MB, Pearson RG, Thuiller W, Erhard M (2005) Validation of species-climate impact models under climate change. Global Change Biol 11:1504-1513

CAFF (Conservation of Arctic Flora and Fauna) (2001) Arctic flora and fauna: status and conservation. Edita, Helsinki

Camill P (2005) Permafrost thaw accelerates in boreal peatlands during late-20th century climate warming. Clim Change 68:135-152

Carter TR, Porter JH, Parry ML (1991) Climatic warming and crop potential in Europe: prospects and uncertainties. Global Environ Change 1:291-312

Christensen TR, Johansson T, Åkermann HJ, Mastepanov M (2004) Thawing of sub-arctic permafrost: effects on vegetation and methane emissions. Geophys Res Lett 31: L04501, doi:10.1029/2003GL018680

Delworth TL, Stouffer RJ, Dixon KW, Spelman MJ, Knutson TR, Broccoli AJ, Kushner PJ, Wetherald RT (2002) Review of simulations of climate variability and change with the GFDL R30 coupled climate model. Clim Dyn 19:555-574

Emori S, Nozawa T, Abe-Ouchi A, Numaguti A, Kimoto M, Nakajima T (1999) Coupled ocean-atmosphere model experiments of future climate change with an explicit representation of sulfate aerosol scattering. J Meteorol Soc Jpn 77:1299-1307

Flato GM, Boer. GJ (2001) Warming asymmetry in climate change simulations. Geophys Res Lett 28:195-198

Fronzek S, Carter TR (2006) Assessing uncertainties in climate change impacts on resource potential for Europe based on projections from RCMs and GCMs. Clim Change (in press)

Gordon C, Cooper C, Senior CA, Banks H, Gregory JM, Johns TC, Mitchell JFB, Wood RA (2000) The simulation of SST, sea ice extent and ocean heat transports in a version of the Hadley Centre coupled model without flux adjustment. Clim Dyn 16:147-168 
Gordon HC, O'Farrell SP (1997) Transient climate change in the CSIRO coupled model with dynamic sea ice. Mon Weather Rev 125:875-907

Guisan A, Theurillat JP (2000) Assessing alpine plant vulnerability to climate change: a modeling perspective. Integrated Assess 1:307-320

Guisan A, Zimmermann NE (2000) Predictive habitat distribution models in ecology. Ecol Model 135:147-186

Hanssen-Bauer I, Forland EJ (2000) Temperature and precipitation variations in Norway 1900-1994 and their links to atmospheric circulation. Int J Climatol 20:1693-1708

Heikkinen RK, Luoto M, Araújo MB, Virkkala R, Thuiller W, Sykes MT (2006) Methods and uncertainties in bioclimatic envelope modeling under climate change. Progr Phys Geogr (in press)

Hoelzle M, Haeberli W (1995) Simulating the effects of mean annual air temperature changes on permafrost distribution and glacier size: an example from the Upper Engadin. Ann Glaciol 21:399-405

Järvinen O, Väisänen RA (1976) Species diversity of Finnish birds. II. biotopes at the transition between taiga and tundra. Acta Zoolog Fenn 145:1-35

Jylhä K, Tuomenvirta H, Ruosteenoja K (2004) Climate change projections for Finland during the 21st century. Boreal Environ Res 9:127-152

Kauppi P, Posch M (1985) Sensitivity of boreal forests to possible climatic warming. Clim Change 7:45-54

Klein Tank A, Wijngaard JB, Können GP, Böhm R and 6 others (2002) Daily dataset of 20th-century surface air temperature and precipitation series for the European Climate Assessment. Int J Climatol 22:1441-1453

Luoto M, Hjort J (2004) Evaluation of current statistical approaches for predictive geomorphological mapping. Geomorphology 67:299-315

Luoto M, Seppälä M (2003) Thermokarst ponds indicating former distribution of palsas in Finnish Lapland. Permafrost Periglacial Processes 14:19-27

Luoto M, Fronzek S, Zuidhoff FS (2004a) Spatial modelling of palsa mires in relation to climate in Northern Europe. Earth Surface Processes Landforms 29:1373-1387

Luoto M, Heikkinen RK, Carter TR (2004b) Loss of palsa mires in Europe and biological consequences. Environ Conserv 31:1-8

Mitchell TD, Carter TR, Jones PD, Hulme M, New M (2003) A comprehensive set of high-resolution grids of monthly climate for Europe and the globe: the observed record (1901-2000) and 16 scenarios (2001-2100). Tyndall Centre Work Pap 55:29

Moisen GG, Frescino TS (2002) Comparing five modelling techniques for predicting forest characteristics. Ecol Model 157:209-225

Monserud RA, Leemans R (1992) Comparing global vegetation maps with the kappa statistic. Ecol Model 62: 275-293

Nakicenovic N, Alcamo J, Davis G, de Fries B and 24 others

Editorial responsibility: Daniel J. Leathers,

Newark, Delaware, USA (eds) (2000) Emissions scenarios. A special report of Working Group III of the Intergovernmental Panel on Climate Change. Cambridge University Press, Cambridge

Nelson FE, Anisimov OE, Shiklomanov NI (2001) Subsidence risk from thawing permafrost. Nature 410:889

New M, Lister D, Hulme M, Makin I (2002) A high-resolution data set of surface climate over global land areas. Clim Res 21:1-25

Parry M (2002) Scenarios for climate impact and adaptation assessment. Global Environ Change 12:149-153

Parry M, Carter T (1998) Climate impact and adaptation assessment-a guide to the IPCC approach. Earthscan Publications, London

Payette S, Delwaide A, Caccianiga M, Beauchemin M (2004) Accelerated thawing of subarctic peatland permafrost over the last 50 years. Geophys Res Lett 31:L18208

Pearce J, Ferrier S (2000) Evaluating the predictive performance of habitat models developed using logistic regression. Ecol Model 133:225-245

Roeckner E, Bengtsson L, Feichter J, Lelieveld J, Rodhe H (1999) Transient climate change simulations with a coupled atmosphere-ocean GCM including the tropospheric sulfur cycle. J Clim 12:3004-032

Ruosteenoja K, Carter TR, Jylhä K, Tuomenvirta H (2003) Future climate in world regions: an intercomparison of model-based projections for the new IPCC emissions scenarios. Finn Environ 644

Seppälä M (1986) The origin of palsas. Geogr Ann 68A: 141-147

Seppälä M (1988) Palsas and related forms. In: Clark MJ (ed) Advances in periglacial geomorphology. John Wiley \& Sons, Chichester, p 247-278

Seppälä M (2003) Surface abrasion of palsas by wind action in Finnish Lapland. Geomorphology 52:141-148

Sollid JL, Sørbel L (1998) Palsa bogs as a climatic indicator examples from Dovrefjell, southern Norway. Ambio 27: $287-291$

Swets K (1988) Measuring the accuracy of diagnostic systems. Science 240:1285-1293

Thuiller W, Araújo M, Lavorel S (2003) Generalized models vs. classification tree analysis: predicting spatial distributions of plant species at different scales. J Veg Sci 14: 669-680

Venables WN, Ripley BD (2002) Modern applied statistics with S. Springer-Verlag, Berlin

Walter H, Breckle SW (1989) Ecological systems of the geobiosphere. Vol. 3. Temperate and polar zonobiomes of northern Eurasia. Springer-Verlag, Berlin

Washington WM, Weatherly JW, Meehl GA, Semtner AJ and 7 others (2000) Parallel climate model (PCM) control and transient simulations. Clim Dyn 16:755-774

Zuidhoff FS, Kolstrup E (2000) Changes in palsa distribution in relation to climate change in Laivadalen, northern Sweden, especially 1960-1997. Permafrost Periglacial Processes 11:55-69

Submitted: June 7, 2005; Accepted: May 31, 2006

Proofs received from author(s): July 18, 2006 